\title{
IMPLEMENTASI PEMASARAN HIJAU MELALUI PENAWARAN TAS BELANJA ECO-BAG UNTUK MENINGKATKAN LOYALITAS PELANGGAN PASAR SWALAYAN
}

\author{
Andika Djunaidi Putra( ${ }^{(1)}$ \\ Ni Wayan Sri Suprapti ${ }^{(2)}$ \\ ${ }^{(1),(2)}$ Fakultas Ekonomi dan Bisnis Universitas Udayana, Bali, Indonesia \\ email: andikadjunaidiputra@gmail.com
}

\begin{abstract}
ABSTRAK
Pasar swalayan adalah salah satu unit bisnis yang ikut berkontribusiterhadap pencemaran lingkungan, terutama yang menyangkutlimbah sampah plastik. Salah satu cara yang dapat diterapkan untuk mengurangi limbah plastikadalah menerapkan green marketing dengan menawarkan tas belanja ramah lingkungan (eco-bag). Penelitian ini dilakukan di Kota Denpasar dan Kabupaten Badung dengan tujuan untuk menjelaskan pengaruh kualitas produk tas belanja eco-bagterhadap loyalitas pelanggan yang dimediasi oleh peran perceived value eco-bag. Data dikumpulkan dengan menggunakan kuesioner dari 105 orang pelanggan di lima pasar swalayan yang menawarkan eco-bag, yang kemudian dianalisis menggunakan analisis Path serta uji Sobel. Hasil penelitian menunjukkan bahwa kualitas produk eco-bag berpengaruh positif dan signifikan, baik terhadap perceived value eco-bagmaupun terhadap loyalitas pelanggan, serta perceived value eco-bag signifikan memediasi pengaruh kualitas produk eco-bag terhadap loyalitas pelanggan.
\end{abstract}

Kata Kunci: kualitas produk tas belanja eco-bag, perceived value, loyalitas pelanggan

\begin{abstract}
Supermarketis one of the business unitsthat cause of the environmental polluted, especially in problem of plastic waste. To reduce this problem, the management of many giant supermarkets offers eco-bag to their customers as implementation of green marketing. This study is conducted in Denpasar City and Badung Regency.The objective of this study is to explain the influence of product quality of eco-bag on customer loyalty, with eco-bag perceived valueas a mediating variable. Data are collected by questionaire from 105 customers of five supermarkets. Dataare analyzed by path analysis and Sobel test. The study found that the product quality of eco-bag is positively influence on customer loyalty, and eco-bag perceived value is significantly mediated the effect of product quality of eco-bag on customer loyalty.
\end{abstract}

Keywords: product quality of eco-bag, perceived value, customer loyalty

\section{PENDAHULUAN}

Pencemaran lingkungan sudah menjadi masalah yang cukup penting belakangan ini. Salah satu penyebabnya adalah meningkatnya sampah plastik. Pasar swalayan menjadi salah satu pihak yang memiliki kontribusi atas permasalahan ini karena menggunakan kantong plastik sebagai tempat menampung barang-barang belanjaan bagi pelanggannya.

Pihak pemerintah pernah mengeluarkan edaran agar manajemen pasar swalayan baik besar maupun kecil untuk membebankan sejumlah biaya tertentu jika konsumen menggunakan kantong plastik untuk menampung barang-barang belanjaannya. Seiring dengan kebijakan ini serta didasari upaya untuk ikut peduli terhadap pelestarian lingkungan, pasar-pasar swalayan besar menempuh strategi menawarkan tas belanja ramah lingkungan kepada pelangganpelanggannya. Penawaran tas belanja yang disebut dengan eco-bag inimerupakan wujud kontribusi perusahaan untuk melaksanakan pemasaran hijau atau green marketing.

Menurut Polonsky (2011), green marketing didefinisikan sebagai seluruh aktivitas yang didesain untuk memfasilitasi setiap perubahan yang dimaksudkan untuk memuaskan kebutuhan atau keinginan manusia dengan seminimal mungkin memberikan dampak negatif terhadap lingkungan.

Provinsi Bali sebagai destinasi wisata dunia yang mengandalkan keunikan budaya dan keindahan alam sebagai daya tarik wisata telah menarik minat para investor untuk membangun jaringan pasar swalayannya. Beberapa pasar swalayan besar yang ada di Bali antara lain TRANS MART CARREFOUR BALI, HYPERMART BALI, FOODMART BALI (berlokasi di Kabupaten Badung) serta GROSERINDO BALI dan LOTTE MART BALI (berlokasi di Kota Denpasar). Terkonsentrasinya pasar-pasar swalayan di kedua kota/kabupaten ini karena pasar sasarannya 
sebagian besar ada di wilayah tersebut. Badung dikenal sebagai kabupaten yang memiliki banyak pusat-pusat wisata (Pantai Kuta, Seminyak, Uluwatu, Nusa Dua, Tanjung Benoa) beserta fasilitas pendukungnya seperti hotel dan restoran sehingga menjadi tempat favorit bagi wisatawan untuk menikmati obyek wisata dan tinggal di sana. Sementara itu, Denpasar adalah ibukota Provinsi Bali sehingga menjadi pusat pemerintahan, pusat perdagangan, pusat pendidikan dan pusat-pusat aktivitas lainnya sehingga menjadi daya tarik penduduk untuk memperoleh peluang kerja, dan akhirnya berdampak pada daya beli masyarakatnya yang relatif lebih tinggi dibandingkan penduduk kabupaten lainnya. Dengan demikian menjadi masuk akal, pasar-pasar swalayan besar memilih dua wilayah ini sebagai lokasi usaha.

Pada umumnya, produk-produk yang ditawarkan oleh pasar swalayan tersebut sangat lengkap dan memiliki kualitas yang relatif lebih baik dibandingkan dengan pasar-pasar swalayan kecil lainnya. Seperti usaha-usaha bisnis lainnya, berbagai langkah dilakukan oleh setiap pasar swalayan untuk menarik pelanggan serta mempertahankan loyalitas pelanggannya. Selain tetap menjamin kualitas dan keragaman produk-produknya, dalam upaya ikut mengimplementasikan pemasaran hijau, pasar-pasar swalayan tersebut menawarkan tas belanja eco-bag dengan daya tarik masing-masing. Tas belanja ini ditawarkan kepada pelanggan dengan harga tertentu. Sebagai gambaran, pada Tabel 1 disajikan data harga tas belanja eco-bag dari kelima swalayan tersebut.

Tampak bahwa dua tas belanja eco-bag dari dua pasar swalayan ditawarkan dengan harga yang sama dan paling rendah (Hypermart Bali dan Food Mart Bali), dua lainnya dengan harga hampir sama namun berada pada harga tertinggi (Groserindo Bali dan Lotte Mart Bali), dan satunya lagi berada di tengah-tengah (Transmart Carrefour Bali). Perbedaan harga disebabkan oleh daya tampung tas yang berbeda, sementara bahan baku atau materialnya hampir sama, yaitu menggunakan kain sejenis drill yang agak tebal dan kuat.

Dalam literatur pemasaran dan perilaku konsumen, produk hijau yang berkualitas diharapkan mampu menimbulkan persepsi nilai bagi pelanggan dan pada akhirnya menumbuhkan kesetiaan atau loyalitas untuk tetap menggunakan produk tersebut. Dalam konteks penggunaan tas belanja yang ramah lingkungan ini, maka kualitas tas belanja itu diharapkan mampu menimbulkan persepsi nilai bagi pelanggan-pelanggan pasar swalayan, yang pada

\section{Tabel 1. Daftar Harga Eco-Bag pada Pasar Swalayan di Kota Denpasar dan Kabupaten Badung}

\begin{tabular}{lll}
\hline No & Nama Swalayan & Harga(Rp) \\
\hline 1 & Transmart Carrefour Bali & $14.900,-$ \\
\hline 2 & Hypermart Bali & $9.900,-$ \\
\hline 3 & Food Mart Bali & $9.900,-$ \\
\hline 4 & Groserindo Bali & $18.000,-$ \\
\hline 5 & Lotte Mart Bali & $17.900,-$ \\
\hline \multicolumn{2}{l}{ Sumber: Survei langsung tanggal 22 } & Oktober 2016
\end{tabular}

akhirnya diharapkan meningkatkan loyalitas mereka untuk berbelanja di pasar swalayan tersebut. Mengingat keragaman dan kualitas produk yang ditawarkan oleh kelima pasar swalayan ini hampir sama, maka penggunaan tas belanja eco-bag diharapkan sebagai daya tarik tersendiri bagi pelanggan untuk tetap setia atau loyal kepada pasar swalayan tertentu, dengan nilai tambah yaitu ikut berkontribusi untuk melestarikan lingkungan dengan tidak menambah sampah plastik. Daya tarik yang dimaksudkan merupakan salah satu bagian dari promosi perusahaan untuk menarik dan mempertahankan pelanggan, karena produk-produk yang ditawarkan tidak memiliki perbedaan atau keunggulan yang menyolok antara satu pasar swalayan dengan pasar swalayan lainnya.

Kualitas menurut Kotler \& Keller (2012:153), adalah keseluruhan ciri serta sifat dari barang atau jasa yang berpengaruh pada kemampuannya untuk memenuhi kebutuhan yang tersurat maupun yang tersirat. Definisi ini berlaku baik untuk menyatakan kualitas produk (barang) maupun kualitas jasa jasa, Kualitas produk, menjadi faktor penting yang berpengaruh dalam penciptaan nilai (perceived value) dan loyalitas pelanggan. Perceived valuedidefinisikan sebagai keseluruhan penilaian konsumen mengenai apa yang diterima berbanding relatif dengan apa yang diberikan (Syamsiah dalam Tanujaya, 2013). Loyalitas secara umum diartikan sebagai kesetiaan, yaitu kesetiaan seseorang terhadap suatu objek. Loyalitas pelanggan dapat diartikan sebagai keinginan atau kesetiaan untuk melakukan pembelian ulang terhadap produk (Tjiptono 2002:85). Loyalitas pelanggan juga didefinisikan sebagai niat (intention) pelanggan untuk tetap bertahan menggunakan layanan dari penyedia layanan berdasarkan pengalaman masa lalu dan harapan masa datang (Wahyuni,2008).

Kesadaran konsumen dalam menggunakan produk ramah lingkungan merupakan wujud keikutsertaan dan tanggungjawab terhadap keselamatan lingkungan (Septifani, 2014). Konsumen yang 
menggunakan eco-bag dalam berbelanja merupakan wujud kesadaran dalam menjaga keselamatan lingkungan. Makin banyaknya konsumen yang memilih menggunakan eco-bag ketika berbelanja tidak hanya karena pilihan lebih tepat tetapi juga karena dapat membantu keberlanjutan lingkungan (Atmoko, 2013).

Penelitian ini bertujuan untuk: (1) menjelaskan pengaruh kualitas produk tas belanja ecobagterhadap perceived value eco-bag; (2) menjelaskan pengaruh kualitas produk tas belanja eco-bagterhadap loyalitas pelanggan untuk berbelanja di pasar swalayan; (3) menjelaskan pengaruh perceived value eco-bag terhadap loyalitas pelanggan; dan (4) menjelaskan peran perceived value eco-bag dalam memediasi pengaruhkualitas produk tas belanjan eco-bag terhadap loyalitas pelanggan untuk berbelanja di pasar swalayan.

Beneke (2013)menghasilkan temuan bahwa kualitas produk berpengaruh positif dan signifikan terhadap nilai pelanggan pada pembelian barang dagangan private label di Afrika Selatan. Jika produk mempunyai harapan pelanggan, maka pelanggan akan senang dan menganggap bahwa produk dapat diterima (Afshar et al., 2011). Hal yang sama juga dinyatakan oleh Korda (2004), yang melakukan studi pada siswa-siswi di Slovenia tentang penggunaan ponsel baru, memperoleh hasil bahwa kualitas produk berpengaruh positif dan signifikan terhadap persepsi nilai. Munisih (2015), menyatakan kualitas produk berpengaruh positif dan signifikan terhadap nilai pelanggan, dimana kualitas produk yang meningkat maka nilai pelanggan juga meningkat dalam pembelian obat pada apotek Dela Semarang. Dalam konteks pasar swalayan yang menawarkan produk dengan kualitas dan keragaman yang hampir sama, maka kualitas tas belanja eco-bag diharapkan mampu menimbulkan perceived value terhadap produk belanja tersebut. H1: Kualitas produk tas belanja eco-bag berpengaruh positif dan signifikan terhadap perceived value.

Irawan dan Edwin (2013), dalam penelitiannya menemukan bahwa kualitas produk berpengaruh positif terhadap loyalitas pelanggan di restoran Por Kee Surabaya. Penelitian Aris (2014) menghasilkan temuan bahwa kualitas produk berpengaruh positif terhadap loyalitas pelanggan dalam pembelian air minum isi ulang. Demikian pula Yasenia dan Edward (2014) yang meneliti loyalitas terhadap produk
Kentucky Fried Chiken (KFC) menghasilkan temuan bahwa kualitas produk memiliki pengaruh positif signifikan terhadap loyalitas pelanggan berdasarkan total pengunjung. Dengan demikian dalam konteks pasar swalayan yang menawarkan produk tas belanja eco-bag, maka diharapkan penawaran ini dapat meningkatkan loyalitas pelanggan untuk tetap berbelanja di pasar swalayan tertentu.

$\mathrm{H} 2$ : Kualitas produk tas belanja eco-bag berpengaruh positif dan signifikan terhadap loyalitas pelanggan untuk berbelanja di pasar swalayan.

Hasil penelitian Widjojo (2013)menyatakan bahwapersepsi nilai pelanggan memiliki pengaruh yang signifikan terhadap terjadinya loyalitas konsumen di Hypermart. Hasil penelitian ini menunjukkan bahwa konsumen akan cenderung lebih loyal kepada toko apabila memiliki persepsi nilai yang baik terhadap toko tersebut. Penelitian Luarn dan Lin (2003) menyimpulkan bahwa persepsi nilai pelanggan memiliki hubungan yang positif dengan loyalitas konsumen. Persepsi nilai pelanggan dan komitmen adalah kombinasi dari bagian konstruk yang menggabungkan dan menentukan loyalitas, dengan komitmen menanamkan pengaruh yang kuat dari kepercayaan, kepuasan pelanggan, dan nilai yang dipersepsikan oleh konsumen. Hal yang serupa juga dinyatakan oleh Soegoto (2013), bahwa persepsi nilai dan kepercayaan berpengaruh secara signifikan terhadap loyalitas konsumen pada konsumen pengguna jasa PT Pandu Express.

H3: Perceived value produk tas belanja eco-bag berpengaruh positif dan signifikan terhadap loyalitas pelanggan untuk berbelanja di pasar swalayan

Perceived value eco-bag diharapkan dapat memediasi hubungan antara kualitas produk ecobagdan loyalitas pelanggan. Menurut Korda dan Borut (2009), perceived value memediasi secara positif dan signifikan hubungan antara kualitas produk yang ditawarkan dengan loyalitas pelanggan Hotel di Slovenia. Penelitian yang dilakukan oleh Yu Chen (2014) terhadap pengunjung restoran di Taiwan juga menyatakan bahwakualitas produk berpengaruh signifikan terhadap loyalitas pelanggan melalui perceived value.

H4: Perceived value produk eco-bag secara signifikan memediasi hubungan antara kualitas produk eco-bag dengan loyalitas pelanggan pasar swalayan 
Berdasarkan penelusuran hasil-hasil studi sebelumnya dan rumusan hipotesis maka kerangka konsep penelitian dapat digambarkan seperti pada Gambar 1.

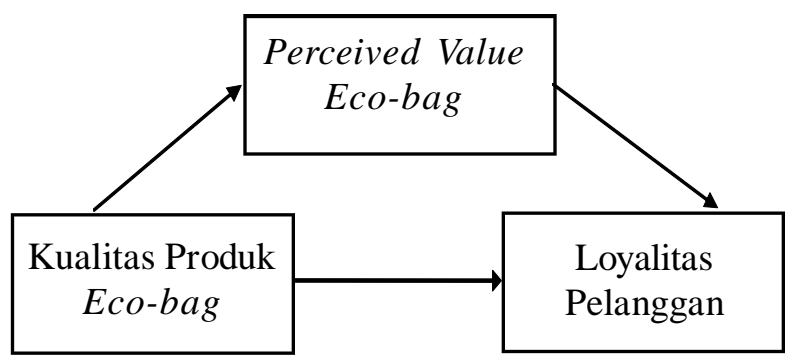

Gambar 1. Kerangka Konseptual Penelitian

\section{METODE PENELITIAN}

Variabel penelitian terdiri atas: (1) kualitas produk tas belanja eco-bag(X), diukur dengan tujuh indikator (manfaat, kekuatan, kecocokan untuk menyimpan barang, estetika, kapasitas, kualitas bahan/material, dan kualitas menyeluruh): 2) perceived value produk eco-bag $(\mathrm{M})$, diukur dengan empat indikator (manfaat ekologis, manfaat ekonomis, ikut peduli lingkungan, dan keseuaian harga dengan kualitas); dan (3) loyalitas pelanggan (Y), diukur dengan lima indikator (selalu belanja di pasar swalayan yang menawarkan eco-bag, melakukan pembelian ulang, senang berbelanja di pasar tersebut, menjadi pilihan utama saat berbelanja, dan merekomendasikan kepada orang lain). Penentuan indikator-indikator variabel diadopsi dan dimodifikasi dari Tjiptono (2009:68); Chen dan Chang (2012), dan Tjiptono dan Chandra (2009:85).

Penelitian ini dilakukan di Kota Denpasar dan Kabupaten Badung dengan menyasar pelanggan dari lima pasar swalayan yang disajikan pada Tabel 1. Data primer diperoleh dari responden penelitian dengan menggunakan instrumen berupa kuesioner yang disebarkan secara langsung di pasar-pasar swalayan. Kuesioner terdiri atas sejumlah pertanyaan tertutup untuk memperoleh data profil responden serta sejumlah pernyataan untuk memperoleh pendapat responden tentang kualitas produk ecobag, perceived value, dan loyalitas pelanggan. Tiap butir pernyataan diukur menggunakan Skala Likert lima poin mulai sangat tidak setuju sampai sangat setuju.

Sebelum disebarkan kepada responden utama, terlebih dahulu dilakukan uji instrumen penelitian menggunakan 30 orang responden. Hasil uji validitas menunjukkan terdapat satu indikator kualitas produk tas belanja eco-bag tidak koefisien korelasi minimal 0,3 sehingga digugurkan (indikator estetika), sedangkan indikator-indikator dari perceived value dan loyalitas pelanggan memenuhi syarat minimal $r>0,3$. Sementara itu hasil uji reliabilitas menunjukkan koefisien Cronbach Alpha lebih besar dari 0,6. Secara berturut-turut koefisien Cronbach Alphakualitas produk eco-bag adalah 0,87; perceived value adalah 0,83 ; dan loyalitas pelangganadalah 0,92 . Dengan demikian seluruh indikator instrumen penelitian berjumlah 15 .

Mengingat populasi pelanggan tidak diketahui, maka sampel bersifat non-probabilitasyaitu ditentukan secara purposif. Sampel ditentukan berdasar beberapa kriteria yaitu minimal berpendidikan SMA, pelanggan di salah satu pasar swalayan dari lima swalayan yang diteliti, serta pernah membeli dan menggunakan tas belanja ecobag yang ditawarkan oleh pasar swalayan yang bersangkutan. Bila menggunakan formula ukuran sampel (5-10) kali jumlah indikator (Sugiyono, 2010:116), maka rentang sampel adalah 75-150, namun dalam penelitian ini ukuran sampel ditetapkan sebesar 7xjumlah indikator yaitu 105 .

Data yang diperoleh dari 105 orang responden dianalisis dengan menggunakan analisis statistik deskriptif dan statistik inferensial. Statistik deskriptif berupa tabel frekuensi dan nilai rata-rata digunakan untuk menyajikan profil atau karakteristik responden dan deskripsi variabel penelitian, sedangkan statistik inferensial berupa analisis jalur (Path analysis) disertai uji Sobel digunakan untuk menguji hipotesis. Namun sebelum dilakukan analisis jalur, terlebih dahulu dilakukan analisis faktor untuk menguji validitas konstruk atau variabel penelitian.

\section{HASIL DAN PEMBAHASAN}

Hasil analisis dengan statistik dekriptif menunjukkan profil responden dan deskripsi variabel penelitian seperti disajikan pada Tabel 2 dan Tabel 3.

Data pada Tabel 2 menunjukkan bahwa proporsi responden laki-laki lebih besar daripada proporsi responden perempuan. Saat ini, pasar swalayan tidak lagi identik sebagai tempat belanja kaum perempuan, dengan kata lain kaum laki-laki sudah banyak menunjukkan peran berbelanja kebutuhan sehari-hari yang sebelumnya disandang oleh perempuan. 
Tabel 2. Profil Responden Berdasarkan Beberapa Variabel Demografis

\begin{tabular}{|c|c|c|c|c|}
\hline No & Variabel & Klasifikasi & Jumlah(orang) & Persentase \\
\hline \multirow{2}{*}{1} & \multirow{2}{*}{ Jenis Kelamin } & Laki-laki & 59 & 56,2 \\
\hline & & perempuan & 46 & 43,8 \\
\hline \multicolumn{3}{|c|}{ Jumlah } & 105 & 100 \\
\hline \multirow{5}{*}{2} & \multirow{5}{*}{ Usia (tahun) } & $<25$ & 71 & 67,6 \\
\hline & & $25-34$ & 9 & 8,6 \\
\hline & & $35-44$ & 14 & 13,3 \\
\hline & & $45-54$ & 8 & 7,6 \\
\hline & & $\geq 55$ & 3 & 2,9 \\
\hline \multicolumn{3}{|c|}{ Jumlah } & 105 & 100 \\
\hline \multirow{3}{*}{3} & Pendidikan & SMA/SMK & 78 & 74,3 \\
\hline & \multirow{2}{*}{\multicolumn{2}{|c|}{$\begin{array}{l}\text { Perguruan Tinggi } \\
\text { Jumlah }\end{array}$}} & 27 & 25,7 \\
\hline & & & 105 & 100 \\
\hline \multirow{6}{*}{4} & \multirow{5}{*}{ Pekerjaan } & Pelajar/Mahasiswa & 42 & 40 \\
\hline & & PNS & 4 & 3,8 \\
\hline & & Wiraswasta & 18 & 17,1 \\
\hline & & Pegawai Swasta & 37 & 35,2 \\
\hline & & Lain-lain & 4 & 3,8 \\
\hline & & & 105 & 100 \\
\hline
\end{tabular}

Sumber : Hasil pengolahan data penelitian

Dilihat dari kelompok usia, responden didominasi oleh konsumen muda berusia di bawah 25 tahun dan umumnya mereka memiliki latar belakang pendidikan SMA/SMK. Sementara dilihat dari pekerjaan, sebagian besar bekerja sebagai karyawan swasta.

Skor rata-rata jawaban responden terhadap setiap indikator dari variabel penelitian yang disajikan pada Tabel 3 dikelompokkan kembali menjadi lima kelas interval dengan interval kelas 0,8 . Interval 0,8 diperoleh menggunakan formula skor tertinggi dikurangi skor terendah dibagi jumlah kelas (Wirawan, 2002:35). Dengan interval 0,8 maka diperoleh lima kelas interval dengan rentang: (1) 1,00-1,79 = Sangat tidak baik; (1) 1,80-2,59= Tidak Baik; (3) 2,60-3,39= Cukup baik; (4) 3,40-4,19= Baik; dan (5) 4,20-5,00 = Sangat baik.

Data pada Tabel 3 menunjukkan bahwa secara keseluruhan rata-rata total skor tanggapan responden mengenai variabel kualitas produk ecobagtermasuk dalam kriteria sangat baik. Hal ini berarti konsumen memandang bahwa tas belanja eco-bag memiliki kualitas yang sangat baik. Skor jawaban responden paling tinggi ditunjukkan oleh pernyataan "Secara keseluruhan, tas belanja ecobag memiliki kualitas yang baik" sedangkan skor terendah ditunjukkan oleh pernyataan "Tas belanja eco-bag cocok digunakan untuk keperluan berbagai barang yang dibeli”.
Untuk variabel perceived valuetas belanja ecobag, skor rata-rata pendapat responden termasuk dalam kriteria sangat baik. Hal ini berarti produk tas belanja eco-bag dipandang oleh responden memiliki nilai sangat tinggi atau sangat baik dibandingkan dengan kantong plastik. Skor rata-rata tertinggi ditunjukkan oleh pernyataan mengenai "Dengan menggunakan tas belanja eco-bag" membuat saya merasa ikut peduli terhadap lingkungan." Hal ini mengindikasikan bahwa konsumen menilai dengan menggunakan tas belanja eco-bag, mereka merasa ikut peduli terhadap lingkungan. Skor terendah dicapai oleh pernyataan" Tas belanja "eco-bag" memberi manfaat ekonomis yaitu dapat digunakan beberapa kali”.

Pendapat responden terhadap variabel loyalitas pelanggan termasuk dalam kategori sangat baik. Artinya bahwa kesetiaan responden untuk berbelanja di pasar swalayan yang menawarkan tas belanja eco-bag termasuk sangat tinggi. Pernyataan yang mencapai skor tertinggi adalah "Saya senang berbelanja di pasar swalayan yang menawarkan tas belanja eco-bag" sedangkan skor terendah ditunjukkan oleh pernyataan "Saya akan melakukan pembelian ulang di pasar swalayan yang menawarkan tas belanja eco-bag".

Sebelum dilakukan pengujian hipotesis, terlebih dahulu dilakukan pengujian konstruk menggunakan analisis faktor. Hasil pengujian yang disajikan pada Tabel 4 menunjukkan semua kriteria telah terpenuhi. 
Tabel 3. Distribusi Jawaban Responden Terhadap Variabel Penelitian

\begin{tabular}{|c|c|c|c|c|c|c|}
\hline \multirow[t]{2}{*}{ Variabel/Indikator } & \multicolumn{5}{|c|}{$\begin{array}{l}\text { Distribusi Jawaban Responden (\%); } \\
n=105\end{array}$} & \multirow{2}{*}{$\begin{array}{l}\text { Rata- } \\
\text { Rata } \\
\text { Skor }\end{array}$} \\
\hline & STS & $T S$ & $N$ & $S$ & $S S$ & \\
\hline \multicolumn{7}{|l|}{ Kualitas Produk Produk Eco-bag (X) } \\
\hline $\begin{array}{l}\text { Tas belanja "eco-bag" sangat bermafaat } \\
\text { digunakan untuk berbelanja di pasar swalayan. }\end{array}$ & 0 & 0 & 13,3 & 38,1 & 48,6 & 4,35 \\
\hline $\begin{array}{l}\text { Tas belanja "eco-bag" tampak lebih kuat } \\
\text { dibandingkan menggunakan kantong plastik. }\end{array}$ & 0 & 0 & 11,4 & 38,1 & 50,5 & 4,39 \\
\hline $\begin{array}{l}\text { Tas belanja "eco-bag" cocok digunakan untuk } \\
\text { keperluan berbagai barang yang dibeli. }\end{array}$ & 0 & 0 & 14,3 & 47,6 & 38,1 & 4,24 \\
\hline $\begin{array}{l}\text { Tas belanja "eco-bag" memiliki kapasitas yang } \\
\text { mampu menampung barang belanjaan di pasar } \\
\text { swalayan }\end{array}$ & 0 & 0,9 & 15,2 & 40,9 & 42,9 & 4,26 \\
\hline $\begin{array}{l}\text { Tas belanja "eco-bag" dibuat dari bahan yang } \\
\text { baik }\end{array}$ & 0 & 0 & 16,2 & 38,1 & 45,7 & 4,30 \\
\hline $\begin{array}{l}\text { Secara keseluruhan, tas belanja "eco-bag" } \\
\text { memiliki kualitas yang baik. }\end{array}$ & 0 & 0 & 16,2 & 38,1 & 45,7 & 4,41 \\
\hline Skor rata-rata kualitas produk tas eco-bag & & & & & & 4,32 \\
\hline \multicolumn{7}{|l|}{ Perceived Value Produk Tas eco-bag (M) } \\
\hline $\begin{array}{l}\text { Tas belanja "eco-bag" memberi manfaat } \\
\text { ekologis berupa pengurangan limbah plastik. }\end{array}$ & 0 & 0 & 11,42 & 43,80 & 44,76 & 4,33 \\
\hline $\begin{array}{l}\text { Tas belanja "eco-bag" memberi manfaat } \\
\text { ekonomis yaitu dapat digunakan beberapa kali. }\end{array}$ & 0 & 0 & 12,38 & 45,71 & 41,90 & 4,30 \\
\hline $\begin{array}{l}\text { Dengan menggunakan tas belanja "eco-bag" } \\
\text { membuat saya merasa ikut peduli terhadap } \\
\text { lingkungan. }\end{array}$ & 0 & 0 & 12,38 & 40 & 47,61 & 4,35 \\
\hline $\begin{array}{l}\text { Saya menilai, manfaat yang diberikan dengan } \\
\text { menggunakan tas belanja "eco-bag" sesuai } \\
\text { dengan harganya. }\end{array}$ & 0 & 0 & 12,4 & 41,9 & 45,7 & 4,33 \\
\hline Skor rata-rata perceived value & & & & & & 4,33 \\
\hline \multicolumn{7}{|l|}{ Loyalitas Pelanggan $(\mathrm{Y})$} \\
\hline $\begin{array}{l}\text { Saya akan selalu berbelanja kebutuhan pokok } \\
\text { di pasar swalayan yang menawarkan tas } \\
\text { belanja "eco-bag" }\end{array}$ & 0 & 0 & 25,71 & 38,09 & 36,19 & 4,10 \\
\hline $\begin{array}{l}\text { Saya akan melakukan pembelian ulang di } \\
\text { pasar swalayan yang menawarkan tas belanja } \\
\text { "eco-bag" }\end{array}$ & 0 & 0 & 24,76 & 37,14 & 38,09 & 4,13 \\
\hline $\begin{array}{l}\text { Saya senang berbelanja di pasar swalayan } \\
\text { yang menawarkan tas belanja "eco-bag" }\end{array}$ & 0 & 0 & 16,2 & 33,3 & 50,5 & 4,34 \\
\hline $\begin{array}{l}\text { Pasar swalayan yang menawarkan tas belanja } \\
\text { "eco-bag" akan selalu menjadi pilihan utama } \\
\text { saya untuk berbelanja kebutuhan sehari-hari. }\end{array}$ & 0 & 0 & 19,0 & 28,6 & 52,4 & 4,33 \\
\hline $\begin{array}{l}\text { Saya akan merekomendasikan pasar swalayan } \\
\text { yang menawarkan tas belanja "eco-bag" } \\
\text { kepada kerabat atau kenalan. }\end{array}$ & 0 & 0 & 19,04 & 30,47 & 50,47 & 4,31 \\
\hline Skor rata-rata loyalitas pelanggan (Y) & & & & & & 4,25 \\
\hline
\end{tabular}

Sumber : Hasil pengolahan data penelitian 
46 Matrik: Jurnal Manajemen, Strategi Bisnis dan Kewirausahaan Vol. 11, No. 1, Februari 2017

Tabel 4. Hasil Pengujian Analisis Faktor

\begin{tabular}{lcccc}
\hline Variabel & KMO & $\begin{array}{c}\text { Total Variance } \\
\text { Explained }\end{array}$ & Indikator & $\begin{array}{c}\text { Factor- } \\
\text { loading }\end{array}$ \\
\hline Kualitas produk tas belanja & 0,829 & 62,300 & $\mathrm{X} 1$ & 0,775 \\
eco-bag (X) & & & $\mathrm{X} 2$ & 0,820 \\
& & & $\mathrm{X} 3$ & 0,772 \\
& & & $\mathrm{X} 4$ & 0,786 \\
& & & $\mathrm{X} 5$ & 0,759 \\
& & & $\mathrm{X} 6$ & 0,821 \\
\hline Perceived value (M) & 0,801 & 70,569 & $\mathrm{M} 1$ & 0,819 \\
& & & M2 & 0,863 \\
& & & M3 & 0,861 \\
& & & M4 & 0,816 \\
\hline Loyalitas pelanggan (Y) & 0,864 & 71,946 & Y1 & 0,875 \\
& & & Y2 & 0,866 \\
& & & Y3 & 0,818 \\
& & & Y4 & 0,822 \\
& & & Y5 & 0,859 \\
\hline
\end{tabular}

Sumber: Hasil pengolahan data penelitian

Selanjutnya pengolahan data menggunakan analisis jalur memberikan hasil sebagai berikut.

\section{1) Hasil analisis regresi substruktur-1}

\begin{tabular}{|c|c|c|c|}
\hline \multicolumn{4}{|c|}{ Variables Entered/Removed } \\
\hline Model & $\begin{array}{c}\text { Variables } \\
\text { Entered }\end{array}$ & $\begin{array}{l}\text { Variables } \\
\text { Removed }\end{array}$ & Method \\
\hline 1 & $\begin{array}{l}\text { Kualitas a } \\
\text { Eco-Bag }\end{array}$ & $\cdot$ & Enter \\
\hline
\end{tabular}

a. All requested variables entered.

b. Dependent Variable: Persepsi Nilai

Model Summary

\begin{tabular}{|c|c|c|c|c|c|c|c|c|c|c|}
\hline \multirow[b]{2}{*}{ Model } & \multirow[b]{2}{*}{$\mathrm{R}$} & \multirow[b]{2}{*}{ R Square } & \multirow[b]{2}{*}{$\begin{array}{l}\text { Adjusted } \\
\text { R Square }\end{array}$} & \multirow[b]{2}{*}{$\begin{array}{l}\text { Std. Error of } \\
\text { the Estimate }\end{array}$} & \multicolumn{5}{|c|}{ Change Statistics } & \multirow[b]{2}{*}{$\begin{array}{l}\text { Durbin- } \\
\text { Watson }\end{array}$} \\
\hline & & & & & $\begin{array}{l}\text { R Square } \\
\text { Change }\end{array}$ & F Change & df1 & $\mathrm{df} 2$ & Sig. F Chang & \\
\hline 1 & $.703^{\mathrm{a}}$ & .494 & .489 & .71472230 & .494 & 100.591 & 1 & 103 & .000 & 2.209 \\
\hline
\end{tabular}

a. Predictors: (Constant), Kualitas Eco-Bag

b. Dependent Variable: Persepsi Nilai

\begin{tabular}{llrrrrr}
\multicolumn{7}{c}{ ANOVA $^{\mathbf{b}}$} \\
\hline Model & & $\begin{array}{c}\text { Sum of } \\
\text { Squares }\end{array}$ & df & Mean Square & F & Sig. \\
\hline 1 & Regression & 51.385 & 1 & 51.385 & 100.591 & .000 a \\
& Residual & 52.615 & 103 & .511 & & \\
& Total & 104.000 & 104 & & & \\
\hline
\end{tabular}

a. Predictors: (Constant), Kualitas Eco-Bag

b. Dependent Variable: Persepsi Nilai

\begin{tabular}{|c|c|c|c|c|c|c|c|c|}
\hline \multicolumn{9}{|c|}{ Coefficients $^{a}$} \\
\hline \multirow[b]{2}{*}{ Model } & & \multicolumn{2}{|c|}{$\begin{array}{l}\text { Unstandardized } \\
\text { Coefficients }\end{array}$} & \multirow{2}{*}{$\begin{array}{c}\begin{array}{c}\text { Standardized } \\
\text { Coefficients }\end{array} \\
\text { Beta }\end{array}$} & \multirow[b]{2}{*}{$\mathrm{t}$} & \multirow[b]{2}{*}{ Sig. } & \multicolumn{2}{|c|}{ Collinearity Statistics } \\
\hline & & $B$ & Std. Error & & & & Tolerance & VIF \\
\hline \multirow[t]{2}{*}{1} & (Constant) & .000 & .070 & & .000 & 1.000 & & \\
\hline & Kualitas Eco-Bag & .703 & .070 & .703 & 10.030 & .000 & 1.000 & 1.000 \\
\hline
\end{tabular}

a. Dependent Variable: Persepsi Nilai 
Berdasar hasil ini dapat disusun persamaan regresi substruktur-1 sebagai berikut.

$\mathrm{M}=\beta_{1} \mathrm{X}+\mathrm{e}_{1}$

$M=0,703 X+e_{1}$

2) Hasil analisis regresi-substruktur-2

Variables Entered/Removedb

\begin{tabular}{llll}
\hline Model & $\begin{array}{l}\text { Variables } \\
\text { Entered }\end{array}$ & $\begin{array}{c}\text { Variables } \\
\text { Removed }\end{array}$ & Method \\
\hline 1 & $\begin{array}{l}\text { Persepsi } \\
\text { Nilai, } \\
\text { Kualitas } \\
\text { Eco-Bag }\end{array}$ & & \\
& & . Enter \\
& & \\
\hline
\end{tabular}

a. All requested variables entered.

b. Dependent Variable: Loyalitas

Model Summary ${ }^{b}$

\begin{tabular}{|c|c|c|c|c|c|c|c|c|c|}
\hline \multirow[b]{2}{*}{ Model } & \multirow[b]{2}{*}{$\mathrm{R}$} & \multirow[b]{2}{*}{ R Square } & \multirow[b]{2}{*}{$\begin{array}{l}\text { Std. Error of } \\
\text { the Estimate }\end{array}$} & \multicolumn{5}{|c|}{ Change Statistics } & \multirow[b]{2}{*}{$\begin{array}{l}\text { Durbin- } \\
\text { Watson }\end{array}$} \\
\hline & & & & $\begin{array}{c}\text { R Square } \\
\text { Change }\end{array}$ & F Change & df1 & df2 & Sig. F Change & \\
\hline 1 & $.860^{\mathrm{a}}$ & .739 & .51586161 & .739 & 144.406 & 2 & 102 & .000 & 1.781 \\
\hline
\end{tabular}

ANOVAb

\begin{tabular}{llrrrrr}
\hline Model & & Sum of & & & & \\
Squares & df & Mean Square & \multicolumn{1}{c}{ F } & Sig. \\
\hline 1 & Regression & 76.856 & 2 & 38.428 & 144.406 & $.000^{\mathrm{a}}$ \\
& Residual & 27.144 & 102 & .266 & & \\
& Total & 104.000 & 104 & & & \\
\hline
\end{tabular}

a. Predictors: (Constant), Persepsi Nilai, Kualitas Eco-Bag

b. Dependent Variable: Loyalitas

\begin{tabular}{|c|c|c|c|c|c|c|c|c|}
\hline \multicolumn{9}{|c|}{ Coefficientsa } \\
\hline \multirow[b]{2}{*}{ Model } & & \multicolumn{2}{|c|}{$\begin{array}{l}\text { Unstandardized } \\
\text { Coefficients }\end{array}$} & \multirow{2}{*}{$\begin{array}{l}\text { Standardized } \\
\text { Coefficients } \\
\text { Beta }\end{array}$} & \multirow[b]{2}{*}{$t$} & \multirow[b]{2}{*}{ Sig. } & \multicolumn{2}{|c|}{ Collinearity Statistics } \\
\hline & & $\mathrm{B}$ & Std. Error & & & & Tolerance & VIF \\
\hline \multirow[t]{3}{*}{1} & (Constant) & .000 & .050 & & .000 & 1.000 & & \\
\hline & Kualitas Eco-Bag & .636 & .071 & .636 & 8.947 & .000 & .506 & 1.977 \\
\hline & Persepsi Nilai & .284 & .071 & .284 & 3.988 & .000 & .506 & 1.977 \\
\hline
\end{tabular}

a. Dependent Variable: Loyalitas

Hasil analisis jalur substruktur 2 dapat disusun ke dalam persamaan matametis sebagai berikut.

$$
\begin{aligned}
& Y=\beta_{2} X+\beta_{3} M+e_{2} \\
& Y=0,636 X+0,284 M+e_{2}
\end{aligned}
$$

Selanjutnya dapat dihitung nilai standar error sebagai berikut.

$$
\begin{aligned}
& \mathrm{e}=\sqrt{1-\mathrm{R} 1^{2}} \\
& \mathrm{e}_{1}=\sqrt{1-\mathrm{R} 1^{2}}=\sqrt{1-0,494}=0,711 \\
& \mathrm{e}_{2}=\sqrt{1-\mathrm{R} 2^{2}}=\sqrt{1-0,739}=0,510
\end{aligned}
$$

Koefisien pengaruh error $\left(e_{1}\right)$ sebesar 0,711 dan pengaruh error $\left(\mathrm{e}_{2}\right)$ sebesar 0,510 digunakan untuk menghitung koefisien determinasi total sebagai berikut:

$$
\begin{aligned}
\mathrm{R}^{2} \mathrm{~m} & =1-\left(\mathrm{Pe}_{1}\right)^{2}\left(\mathrm{Pe}_{2}\right)^{2} \\
& =1-(0,711)^{2}(0,510)^{2} \\
& =0,869
\end{aligned}
$$

Nilai determinasi total sebesar 0,869 mempunyai arti bahwa sebesar $86,9 \%$ variasi loyalitas pelanggan untuk berbelanja di pasar swalayan dijelaskan oleh variasi kualitas produk tas belanja eco-bag dan variasi perceived value eco-bag, sedangkan sisanya sebesar $13,1 \%$ dijelaskan oleh faktor lain yang tidak dimasukkan ke dalam model. 
Pada Tabel 5 disajikan data rekapitulasi hasil pengujian hipotesis. Hasil tersebut menunjukkan bahwa hipotesis 1-3 memperoleh dukungan.

Hasil uji hipotesis seperti disajikan pada Tabel 5 menunjukkan pengaruh langsung antar variabel penelitian. Pengaruh tak langsung variabel kualitas produk tas belanja eco-bag (X) terhadap variabel loyalitas pelanggan $(\mathrm{Y})$ melalui variabel perceived value (M) sebagai mediasi dapat dihitung dengan mengalikan koefisien pengaruh $\mathrm{X} \rightarrow \mathrm{M}$ dan koefisien pengaruh $\mathrm{Y} \rightarrow \mathrm{M}$ yaitu sebesar $(0,703 \times 0,284)=0,199$.

Peran perceived value sebagai vaiabel mediasi diperiksa dengan menggunakan uji Sobel (Preacher \& Hayes, 2004) dengan formula berikut.

$$
S a b=\sqrt{a^{2} S b^{2}+b^{2} S a^{2}+S a^{2} S b^{2}}
$$

Selanjutnya dihitung nilai $\mathrm{Z}$ dengan formula berikut:

$$
\mathrm{Z}=\frac{a b}{S a b}
$$

Keterangan:

$$
\begin{aligned}
& \mathrm{a}=0,703 \\
& \mathrm{Sa}=0,070 \\
& \mathrm{~b}=0,284 \\
& \mathrm{Sb}=0,071
\end{aligned}
$$

$$
\begin{aligned}
\mathrm{z} & =\frac{0,703 \cdot 0,284}{\sqrt{0,703^{2} 0,071^{2}+0,284^{2} 0,07^{2}+0,07^{2} 0,071^{2}}} \\
\mathrm{z} & =\frac{0,199652}{\sqrt{0,002491308+0,0003952144+2,47009 e-5}} \\
\mathrm{z} & =3,70029142 \\
& =3,7
\end{aligned}
$$

Hasil nilai Z sebesar 3,7 yang lebih besar dari pada 1,96 (nilai tabel) menunjukkan bahwa perceived value eco-bag dinilai secara signifikan memediasi pengaruh kualitas produk ecobagterhadap loyalitas pelanggan pasar swalayan. Dengan demikian hipotesis-4 memperoleh dukungan sehingga dapat dihitung pengaruh total variabel kualitas produk tas belanja eco-bag terhadap variabel loyalitas pelanggan yaitu $0,636+0,199=0,835$.

Berdasarkan pengujian hipotesis, maka dapat digambarkan diagram jalur seperti Gambar 2.

\section{Pembahasan}

Tujuan pertama dari penelitian ini adalah untuk menjelaskan pengaruh kualitas produk tas belanja eco-bag terhadap perceived value eco-bag. Hasil pengujian yang terdapat dalam Tabel 5 menunjukkan hipotesis terdukung. Hasil ini memiliki makna bahwa makin baik kualitas produk tas belanja eco-bag yang ditawarkan oleh pasar swalayan maka akan menimbulkan persepsi nilai yang makin baik bagi pelanggan. Dengan kata lain, kualitas tas belanja eco-bag yang ditunjukkan oleh: (1) manfaatnya untuk berbelanja di pasar swalayan; (2)tampak lebih kuat dibandingkan kantong plastik; (3) cocok digunakan untuk menampung barang-barang keperluan belanja; (4) kapasitasnya yang cukup untuk menampung barang belanjaan; dan (5) teruat dari bahan yang baik, telah menyebabkan perceived value pelanggan terhadap tas belanja tersebut menjadi makin baik. Dalam hal ini, perceived value pelanggan dilihat dari indikator: (1) tas belanja tersebut telah memberi manfaat ekologis yaitu ikut mengurangi limbah plastik; (2) manfaat ekonomis karena bisa digunakan berkali-kali; (3) membuat konsumen

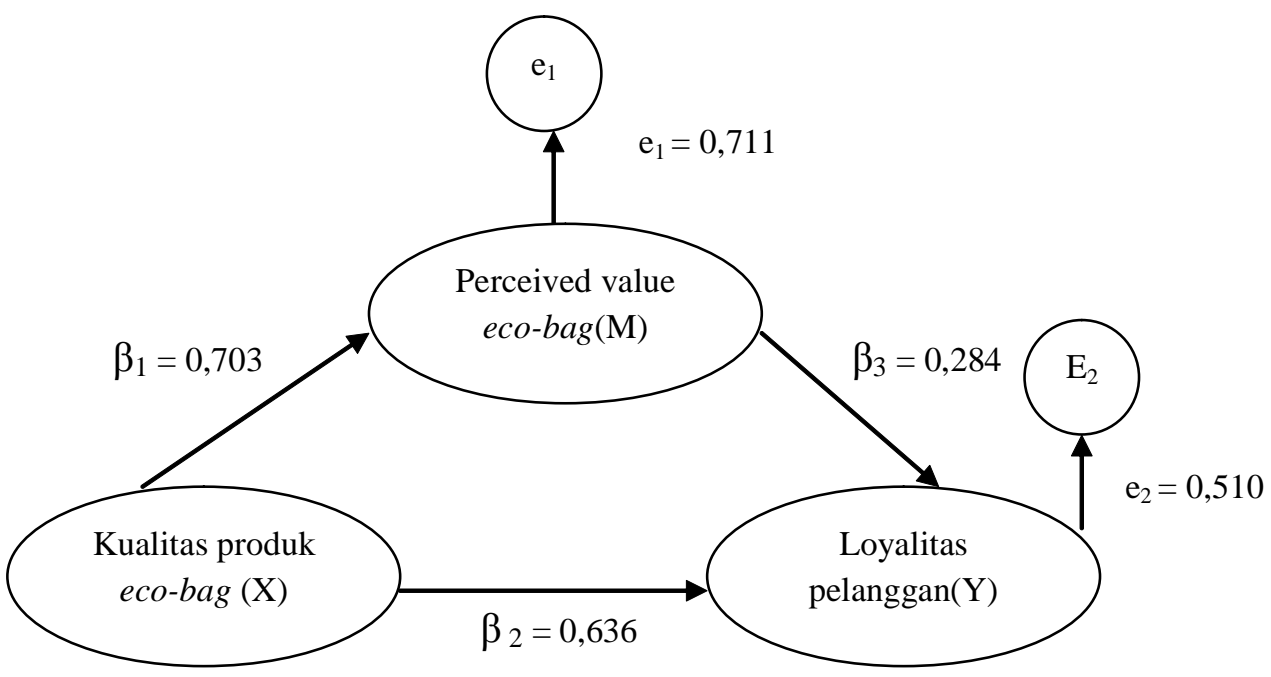

Gambar 2. Model Diagram Jalur Akhir 
merasa ikut peduli terhadap lingkungan; serta (4) manfaat yang diberikan sesuai dengan harganya.

Hasil penelitian ini sesuai dengan penelitian sebelumnya yang telah dilakukan oleh Beneke(2013) yang menghasilkan temuan bahwakualitas produk memiliki pengaruh positif terhadapnilai pelanggan pada pembelian barang dagangan private label di Afrika Selatan. Afshar et al., (2011) menyatakan jika produk mampu memenuhi harapan pelanggan, maka pelanggan akan senang dan menganggap bahwa produk dapat diterima. Korda (2004) yang melakukan studi pada siswa-siswi mengenai penggunaan ponsel baru di Slovenia menemukan bahwakualitas produk berpengaruh positif dan signifikan terhadap nilai pelanggan. Studi oleh Munisih (2015) tentang pembelian obat di Apotek Dela Semarang juga menghasilkan temuan bahwa kualitas produk berpengaruh positif dan signifikan terhadap nilai pelanggan.

Tujuan penelitian yang kedua adalah untuk menjelaskan pengaruh kualitas produk tas belanja eco-bagterhadap loyalitas pelanggan untuk berbelanja di pasar swalayan. Hasil pengujian yang terdapat dalam Tabel 5 menunjukkan hipotesis memperoleh dukungan, artinya bahwa bahwa makin baik kualitas produk tas belanja eco-bag yang ditawarkan oleh pasar swalayan maka membuat pelanggan menjadi loyal untuk berelanja di pasar swalayan yang menawarkan eco-bag. Dalam hal ini, loyalitas pelanggan dilihat dari indikator: (1)pelanganakan selalu berbelanja pada pasar swalayan yang menawarkan tas belanja eco-bag; (2) pelanggan selalu melakukan pembelian ulang pada pasar swalayan yang menawarkan eco-bag; (3)pelanggan merasa senang berbelanja di pasar swalayan tersebut; (4) pasar swalayan itu akan selalu menjadi pilihan utama untuk berbelanja; serta (5)akan merekomendasikan pasar swalayan yang menawarkan tas belanja eco-bag kepada kerabat dan kenalan.Dengan kata lain, hasil studi menunjukkan bahwa makin baik kualitas tas belanja eco-bag telah menyebakan kelima indikator ini menjadi makin kuat membentuk loyalitas pelanggan untuk berbelanja di pasar swalayan yang menawarkan tas belanja eco-bag.

Hasil penelitian ini mendukung hasil penelitian Irawan dan Edwin (2013), yang menyatakan kualitas produk berpengaruh terhadap loyalitas pelanggan restoran Por Kee Surabaya. Aris (2014) yang meneliti air minum isi ulang menghasilkan temuan bahwa kualitas produk berpengaruh positif terhadap loyalitas pelanggan. Penelitian Yasenia dan Edward (2014) tentang produk ayam goreng KFC menghasilkan temuan bahwa kualitas produk memiliki pengaruh signifikan terhadap loyalitas pelanggan berdasarkan total pengunjung.

Tujuan penelitian yang ketiga adalah untuk menjelaskan pengaruh perceived value eco-bag terhadap loyalitas pelanggan. Hasil pengujian yang disajikan dalam Tabel 5 menunjukkan hipotesis terdukung. Hasil ini memiliki makna bahwa semakin tinggi perceived value terhadap eco-bag maka akan membuat pelanggan menjadi loyal untuk berbelanja di pasar swalayan yang menawarkan ecobag tersebut.

Hasil penelitian ini mendukung beberapa hasilpenelitian sebelumnya. Widjojo (2013) menyatakan persepsi nilai pelanggan memiliki pengaruh yang signifikan terhadap terjadinya loyalitas konsumen di Hypermart. Luarn dan Lin (2003) menyimpulkan bahwa persepsi nilai pelanggan memiliki hubungan yang positif dengan loyalitas konsumen. Hal yang serupa juga dinyatakan oleh Soegoto (2013) bahwa persepsi nilai pelanggan dan kepercayaan berpengaruh secara signifikan terhadap loyalitas konsumen pada konsumen pengguna jasa PT Pandu Express.

Tujuan penelitian yang keempat adalah menjelaskan peran perceived value eco-bag dalam memediasi pengaruh kualitas tas belanja eco-bag terhadap loyalitas pelanggan. Hasil pengujian menunjukkan bahwa perceived value secara signifikan berperan sebagai variabel mediasi, yang artinya bahwa pengaruh kualitas produk tas belanja eco-bag dijembatani oleh variabel peceived value. Pada mulanya kualitas produk tas belanja eco-bag menyebabkan peceived value pelanggan meningkat dan pada akhirnya menyebabkan loyalitasnya untuk berbelanja di pasar swalayan yang menawakan ecobag menjadi makin meningkat pula. Meski demikian, kualitas produk tas belanja eco-bag yang makin baik juga mampu secara langsung menyebabkan loyalitas pelanggan makin meningkat. Dengan kata lain, kualitas produk tas belanja eco-bag memiliki pengaruh langsung dan tak langsung terhadap loyalitas pelanggan.

Hasil penelitian ini sesuai dengan penelitian sebelumnya oleh Korda dan Borut (2009) yang menghasilkan temuan bahwa perceived value secara signifikan memediasi hubungan antara kualitas produk yang ditawarkan dengan loyalitas konsumen Hotel di Slovenia. Penelitian yang dilakukan oleh Yu Chen (2014), menyatakan kualitas produk berpengaruh signifikan terhadap variabel loyalitas konsumen melalui perceived value pada konsumen restorant di Taiwan. 


\section{SIMPULAN DAN SARAN}

Hasil pengujian yang mendukung semua hipotesis menunjukkan bahwa hasil studi yang menyasar pelanggan-pelanggan dari lima pasar swalayan di Kota Denpasar dan Kabupaten Badung ini telah memberi dukungan empiris tentang hubungan variabel kualitas produk tas belanja ecobag dengan variabel perceived value dan loyalitas pelanggan untuk berbelanja di pasar swalayan yang menawarkan eco-bag. Secara spesifik hasil studi ini telah memperkuat hasil-hasil studi terdahulu dengan menyatakan bahwakualitas produk ecobagmerupakan variabel yang dapat digunakan untuk meningkatkanperceived value eco-bag dan meningkatkan loyalitas pelanggan serta perceived value eco-bag merupakan variabel yang mampu memediasi pengaruh kualitas produk tas belanja ecobag terhadap loyalitas pelanggan.

Dilihat dari aspek praktis, maka hasil studi ini mengindikasikan bahwa bila pihak manajemen ingin mempertahankan dan atau meningkatkan loyalitas pelanggannya, maka salah satu strategi yang bisa ditempuh adalah dengan meningkatkan kualitas produk tas belanja eco-bag yang selama ini ditawarkan. Meskipun tiap indikator dari kualitas produk tas belanja eco-bag ini telah dinilai dalam kategori sangat baik, perbaikan dalam hal kualitas hendaknya tetap dilakukan mengingat volume belanja konsumen yang makin banyak serta selera mereka yang selalu mengalami perubahan. Selain perbaikan dalam kapasitas tas, perbaikan juga dapat dilakukan dengan menambah kekuatannya.

Penelitian ini dilakukan di dua kota/kabupaten dengan ukuran sampel yang terbatas sehingga hasilnya tidak bisa digeneralisasi. Karena itu, penelitian yang akan datang hendaknya melibatkan pelanggan-pelanggan dari pasar-pasar swalayan lain, tentu yang menawarkan tas belanja eco-bag, serta dilakukan di wilayah lain di Bali bahkan di Indonesia dengan ukuran sampel yang lebih besar.

Penelitin ini juga hanya fokus pada kualitas produk tas belanja eco-bag sebagai variabel independen, dengan menganggap bahwa kualitas dan keragaman produk utama yang ditawarkan oleh kelima pasar swalayan serta kualitas pelayanan yang diberikan adalah relatif sama. Penelitian selanjutnya akan memberi penjelasan yang lebih baik apabila kedua variabel tersebut dimasukkan ke dalam model. Selain itu, penjelasan terhadap fenomena penggunaan tas belanja eco-bag ini akan menjadi lebih baik pula apabila sampel dikelompokkan berdasar tingkat kepedulian konsumen terhadap lingkungan, sehingga menjadi makin jelas terlihat segmen pasar yang lebih efektif disasar atau ditawari produk-produk yang ramah lingkungan.

\section{REFERENSI}

Afshar, A. J., Mohammad A.H.G, Seyed A.M., Khaled N., and Seyed M.S.K. 2011. Study the Effects of Customer Service and Product Quality on Customer Satisfaction and Loyalty (automotive industries). Journal of Humanities and Social Science. 1(7), pp:253-260.

Atmoko, W., B., dan Setyawan D. 2013. Green Marketing: Memperkuat Daya Saing Merek Melalui Green Brand Equity Proceeding Seminar Nasional dan Call for Papers Sancall 2013. pp:159-167.

Aris. A. 2014. Pengaruh Kualitas Pelayanan dan Kualitas Produk eco-bag terhadap Loyalitas Pelanggan Air Minum Isi Ulang Biru. Jurnal Pendidikan Tata Niaga. 2(3), pp: 001-008.

Beneke, J., Flynn, R., Greig, T., Mukaiwa, M. 2013. The Influence of Perceived Product Quality, Relative Price and Risk on Customer Value and Willingness to Buy: A Study of Private Label Merchandise. The Journal of Product and Brand Management. Pp.218-228.

Irawan D, Japarianto. E, 2013. Analisa Pengaruh Kualitas Produk eco-bag terhadap Loyalitas melalui Kepuasan sebagai Variabel Intervening Pada Pelanggan Restoran Por Kee Surabaya. Jurnal Manajemen Pemasaran. 1(2), pp: 1-8.

Korda, A. Pisnik and Borut, M. 2009. The Importance of Perceived value eco-bagin Evaluating Hotel Guest Statisfaction: The Case of Slovenia. European Journal of Business dan Management, pp:101-122

Korda, A., P., Mumel, D,. 2004. The Relationships Among Perceived Quality, Perceived Risk and Perceived Product Value. The Journal of Product and Brand Management.pp:156-167.

Kotler, P. and K.L. Keller. 2012. Marketing Management. $14^{\text {th }}$ Edition.New York: Pearson Education.

Luarn, P. and H.H. Lin. 2003. A Customer Loyalty Model for E-Service Context, 4(4), pp: 156167.

Munisih, S. 2015. Pengaruh Kualitas Produk ecobag terhadap Nilai Pelanggan dan Dampaknya pada Loyalitas Pelanggan Apotek Dela Semarang. Prosiding Seminar Nasional dan Call for Paper. Fakultas Ekonomika dan Bisnis. Universitas Stikubank Semarang, pp:1-16.

Polonsky, MJ. 2011. Transformative Green Marketing: Impediments and Oportunities. 
Journal of Business Research. 64(12),pp: 1311-1319.

Preacher, K.J. and Hayes, A.F. 2004. SPSS and SAS Procedure for Estimating Indirects Effect in Simple Mediation Model. Behavior Reseacrh Methods, Instruent, and Computer. 36 (4). Pp.717-731.

Septifani, R., Fuad, A., dan Santoso, I .2014. Pengaruh Green Marketing, Pengetahuan dan Minat Membeli terhadap Keputusan Pembelian. Jurnal Manajemen Teknologi, 13(2), pp: 201-218.

Soegoto,, A.S.2013. Pengaruh Persepsi Nilai dan Kepercayaan terhadap Kepuasan dan Dampaknya terhadap loyalitas Konsumen. Fakultas Ekonomi dan Bisnis Universitas Sam Ratulangi Manado, 1(3). pp: 1271-1283.

Sugiyono. 2010. Metode Penelitian Kuantitatif Kualitatif dan $R \& D$. Bandung: Alfabeta

Tanujaya, A. 2013. Pengaruh Customer Perceived Value terhadap Customer Loyalty melalui Customer Satisfaction pada Second Royal Plaza Surabaya. Jurnal ilmiah mahasiswa manajemen, 1(2), pp: 001-006.

Tjiptono, F.2002. Strategi Bisnis, Edisi Pertama. Yogyakarta: Andi Offset
Tjiptono,F. dan Chandra, G. 2009. Pemasaran Strategik. Yogyakarta: Andi Offset.

Wahyuni, Dewi Urip. 2008. Pengaruh Motivasi, Persepsi dan Sikap Konsumen terhadap Keputusan Pembelian Sepeda Motor Merk Honda di Kawasan Surabaya Barat. Jurnal Manajemen dan Kewirausahaan, 10(1), pp:30-37.

Widjojo, P.O.2013. Pengaruh Persepsi Nilai Pelanggan dan Kepuasan Konsumen terhadap Loyalitas Konsumen Hypermart Pawukon Trade Center di Surabaya. Kajian Ilmiah Mahasiswa Manajemen.2(4), pp: 1-5.

Yasenia, dan Siregar H., E. 2014. Pengaruh Kualitas Layanan dan Produk terhadap Kepuasan serta Loyalitas Pelanggan Kentucky Fried Chicken di Tangerang Selatan. Fakultas Ekonomi dan Manajemen Institut Pertanian Bogor, 5(3), pp: 184-199.

Yu Chen, K. 2014. Assessing The Effects of Restaurant-Related Attributes on Customer Behavioral Intention. Journal International Ekonomika, 153(3), pp: 134-140. 